UC-NRLF

(1)

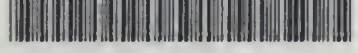
$B$ ᄅ 906 575 


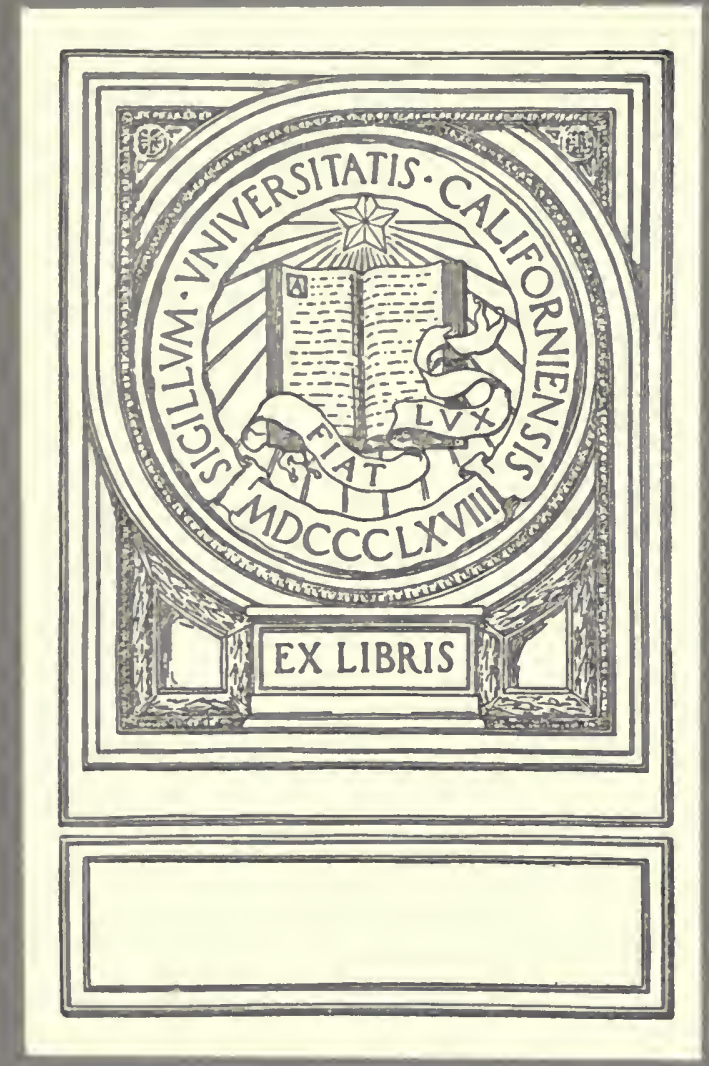





\section{PROVINCE OF/BRITISH COLUMBIA}

\section{DEPARTMENT OF AGRICULTURE}

— (Live-stock Branch)

\section{THE CULTIVATION OF ALFALFA}

BULLETIN No. 40

(Second Edition)

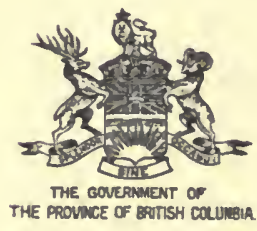

PRINTED BY

AUTHORI'Y OF THE LEGISLATIVE ASSEMBLY

VIOTORIA, B.C.:

Printed hy Tillias H. CuluiN, Printer to the King's Most Fxcellent Majesty. 
Digitized by the Internet Archive in 2007 with funding from Microsoft Corporation 


\section{Departient of Agriculture, Victoria, B.C., January, 1914.}

Hon. Price Ellison,

Minister of Agriculture.

Sir,-I have the honour to submit herewith Bulletin No. 40, dealing with the production of Alfalfa, and which has been compiled by $\mathrm{H}$. Rive, B.S.A., Provincial Dairy Instructor.

I have the honour to be,

Sir,

Your obedient servant,

WM. E. SCOTT,

Deputy Minister of Agriculture. 


\section{PROVINCE OF BRITISH COLUMBIA}

\section{DEPARTMENT OF AGRICULTURE}

(LIVE-STOCK BRANCII)

HON. PIRICE ELLISON, Minister of Agriculture.

WM. E. SCOTT, Deputy Minister of Agriculture.
W. 'I. MCDONALD, B.S.A., M.S.A., Live-stock Commissioner.

H. RIVE, B.S.A., Chicf Dairy Instructor.

J. R. TERIRI,

Chicf l'oultry Instructor.

A. KNIGHT, V.S.,

Chicf Vetcrinary Inspector.

H. I. WALKER, B.S.A., Agriculturist.
J. C. READEY, B.S.A., Soil and Crop Instructor.
II. I. UP'TON,

I'oultry Instructor.

T. A. F. WIANCKO,

Dairy Instructor.
S. A. K. WHITE, V.S., Teterinary Inspector.
W. W. AL'YOX, V.S., Vetcinary Inspector.
B. R. II.SI.EY, V.S., Veterinary Inspector.
WM. J. BONAYIA, Scerctary of the Department. 


\title{
THE CULTIVATION OF ALFALFA.
}

\author{
By H. IRIVe, B.S.A., Provincial Dairy Instructor.
}

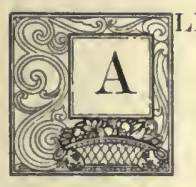

FALFA (Mcdicago sativa), or lucerue, is a peremial of the I.egume family, hardy in mature. It produces stems of an upright, lranching growth, varying in height, in mature plants, from 1 to $3 \frac{1}{2}$ feet. When the plant is young it possesses oue single stem, but the number increases with the age of the plant and the frequency of cutting, until thirty, forty, or more stalks, rapidly lecoming woody as the blossoms develop, are found growing from the one crown. The leaves are not large lut numerous, and are attached by slender stems which grow very brittle with drying, and drop off easily during the process of curing. 'The flowers appenr toward the top of the plant, and the arrangement of the blulsh-purple clusters causes alfalfa to resemble the vetch rather than clover in this particular. The seeds, borne in spiral pods, are of the size of those of red clover, but are not as uniform in shape. Their colour is a light olive-green, offering a contrast to the purple and yellow of clover-seed. Long tap-roots penetrate the earth deeply where the subsoil permits, and if hindered in this they branch out more in their search for food.

Alfalfa is said to be more widely distributed over the earth's surface, to furuish more food for live-stock, and to lave leen cultivated for a longer period than any other legume. It thrives on soils of varions kinds and elevations, in cllmates of different degrees of temperature and of different amounts of ralufall. In our own Province, for many years, large ylelds have been olitahed in the nelghbourliood of Asheroft and in the Okanagan Valley. It is grown in the Bomulary comtry, in the Upper Columbia Valley, in Chilliwack, and on Vancouver Island.

\section{VARIETIES.}

Many varieties of the plant exist. 'They differ from each other more in their ability to withstand heat, cold, and drought than in the quality of food mroduct obtained from them. Of the many introduced or developed and experimented with on this Continent, the varjeties known as Turkestan and Grimms seem hest alapted to northern areas.

\section{SOILS.}

Alfalfa will grow in many soils, providing they are fairly fertile, sulliciently porous below to eary away water with reasonable quickness, and not underlald with hard-pan or a subsoil so stiff that it is almost impervious. The best growth can be obtained on a deep, well-drained fertlle soll, free from weels and from acidity. A sandy loam orer a loose subsoll would offer this, and is preferred by the plant, yet on a clay loam it proves prosperous if access to the subsoll is furnished the roots. A subsoil rich in plant-food is, of conrse, desiralle, but permeability in the lower soil is still more important than fertllity, and on this account a sandy subsoil deficient in plant-food may give better success than clayey subsoll under a similar surface soil. Inrainage to a depth of 30 or 36 inches should readily occur, and the level of the gromd-water should be several feet below the surface during the growing season, as root-growth stops on striking saturated soll. Solls naturally wet, or likely to be under water, or saturated for many hours at a tiris. are not fitted for this nurpose.

In brief, it may be sifd that the lands best adanted to the growing of alfalfa are the slopes and rolling lands of ralleys and the deep sandy loam bottoms welt above water-lerel. Low, flat ralley lands are not suitable. 


\section{ACIDITY AND LIMING.}

Alfalfa will not thrive in an acid soil. By thorongh drainage, aeration of the soil, and the application of lime, acidity may be largely remedied. Liming alone will not be sufficient if the sourness be due to lack of drainage, and this should receire first attention. The soil should then be put into good physical condition by tillage, when, if lime be required, this substance can do its work thoroughly.

Ground limestone is the most economical form in which to apply lime to the soil, but in other forms it is used with good results. Water-slaked lime most quickly corrects acidity; ground unburned limestone more slowly, but less expensirely. If ground limestone be used, at least $2,000 \mathrm{lb}$. per acre should be applied rery early in the spring, or during the year preceding the sowing of alfalfa, which is better. Water-slaked lime is preferred to the air-slaked, as a larger percentage is at once effective. It mas be applied at the rate of about 1,200 lb. per acre. A half-peck heap to erery two square rods will gire a dressing of 1,000 lb. Add water to each heap sparingly, and corer with a couple of inches of earth. Then, later, mix the dry powder that results with earth; spread erenly and harrow in.

Ground limestone is best suited for liming light lands; the caustic lime for heary ones. Too frequent application of caustic lime to a soil may exhaust the nitrogenous matter contained in the humus.

Lime may be added by means of light annual dressings of gypsum or landplaster. This attacks insoluble compounds in the soil, particularly those of potash, setting free the constituents. To apply about $50 \mathrm{lb}$. per acre in the spring is recommended.

Besides correcting acidity, lime exerts a farourable effect upon the physical condition of soils. It helps to separate the adhesive particles of clay, makes heavy soils loose and friable, and increases the absorbing and retaining power of sandy soils. It may occur. in cases where acidity is present, that the unfarourable conditions are due, not to it solely, but to compact texture or lack of aeration, which the incorporation of lime and the accompanying tillage will remedy.

\section{PREPARATION OF THE SOIL.}

Preparation of the soil for alfalfa should begin with the preceding crop, applying lime, if necessary, at that time. To obtain a successful growth, the land must be clean, fertile, and in good physical condition. The young alfalfa-plant is delicate and unable to cope with weeds, which deprire it of food, moisture, and sunlight. Thoroughly cultirated crops, such as kale, corn, potatoes, or roots, assist greatly in removing weeds and, being generally well manured, leave the ground clean and fertile. Summer fallowing is excellent, but a complete or bare fallow is not necessary. Clover-sod, pasture land, or a green crop ploughed under in early fall, cultivated and rolled frequently, then ploughed again, stirring the subsoil if thought advisable, brings good results. By this addition of humus the amount of plant-food is increased and the texture of the soil improved. Leaving the soil in ridges for winter allows access to the air and facilitates drainage.

A sandy or loose soil demands both humus and arallable plant-food. These can be supplled by means of either green crops or farmyard manure, and, if the latter te used, it will best serre its purpose applied heavlly to the crop preceding alfalfa. This allows time for it to become incorporated with the soil and for the germination and destruction of weed-seeds that may be in it. One authority appears to consider that the successful inoculation of soil occurs in sufficiently direct proportion to the supply of barnyard manure to demand careful attention to this point.

Where a heavy rainfall prevails during the winter, followed by a vigorous weedgrowth in the early spring, fall sowing of alfalfa is not successful. $\boldsymbol{\Lambda}$ s early as possible in the spring the land should be cultirated and harrowed, until a seed-bed, fine, smooth, and mellow, is secured, and all weed-sceds near to the surface will hare sprouted and are killed. Spring ploughing, where possible, should be aroided, as a deep, loose seed-bed is not desirable. 
Upon the fertility and physical condition of the surface soil the success of the crop during the first year largely depends, while the state of the subsoil, in great measure, is responsible for its welfare in succedng years.

\section{INOCULATION.}

It is a well-known fact that crops such as alfalfa, clorer, peas, beans, vetches, and others of the same sub-order of the Iegumes thrive best only when certain bacteria are present in the soil in which they are grown. These bacteria form enlargements or nodules on the plant-roots, and make use of the free nitrogen of the air, transferring it to the plauts. Each of these legumes appears to requile bacteria peculiarly suited to itself, though the idea is advanced that certaln closely related groups of this sub-order, including cultivated plants and weeds, possess bacteria which adapt themselves to different plants within these groups. "If nitrogen be well supplied in a soil, alfalfa, for a time, may grow fairly well without this bacterial assistance, but its presence undoubtedly increases both the quantity and quality of the crop, and ultimately must be secured. In most cases, therefore, where alfalfa is sown for the first time, inoculation by some artificial means is necessary to secure good plant-development.

The surest and most practical method is, before sowing the seed, to scatter broadcast over the seed-bed, and harrow in, soll from the surface foot of an old alfalfa-field. About $200 \mathrm{lb}$. of soil per acre should be used, and care taken to obtain it from a clean spot to prevent the introduction of weed-seeds. Aroid exposing this soll to the direct sunlight before scattering and harrowing it in, as such exposure is detrimental to the bacteria.

Inoculation may be effected by mixing and drilling in with the seed a quantity of dry soil, rich in the required germs, and thls way is recommended by some stations, as it offers a vehicle for the small amount of seed used, ensuring thorough distribution. Pure cultures of the bacteria sent ont by agricultural stations may be used, but they cannot be said to have given quite as good results as the inoculated soil. Where this is not available, howerer, the cultures prove of immense ralue. Immediately after inoculation the seeding should take place.

\section{SEED AND SOWING.}

The quality of the seed is of rital importance. It should be large, uniforin, bright, of good vitality, and free from impurities. Brown and discolonred seeds should be avolded; they are usually dead. 'It is wise to secure a sample before the bulk of the seed is purchased, to test its germinating quality by placing a number of the seeds between sheets of moist blotting-paper and keeping them warn. The percentage of poor seed can be estimated as germination occurs, and should not be over 10 per cent. From 16 to $20 \mathrm{lb}$. of seed per acre wlll be found suitable. The seed may be broadcasted and harrowed in, but a far more even and rigorous strand will be secured by drilling.

If a nurse crop be used, the alfalfa-seed can be put into the grass-seed attachment and dropped ahead. A nurse crop for alfalfa in British Columbia is of doubtful benefit, especially in the drier non-irrigated sections. If used, It should be either of wheat or barley, or a mixture of both sown quite thinly, not much more thau one bushel per acre belng used. Oats have a greater tendency to smother the young alfalfa-plants.

Without a nurse erop, the drill set fairly shallow with the sprouts pointing backwards is probably best. It is not adrisable to place the seed at a depth of more than an inch and a half. If difficulty is experlenced in adjusting the arill to small amounts, mlxing the seed with twice its bulk of nieal of some kind will assist. It will be found that drilling in half of the seed at a time, crosswise, will glre a more eren and a better catch. Roll the ground after seeding, and harrow lightls. A brush harrow is rery good for this purpose. 
The date of seeding will depend upon the locality. It is well to delay this operation until sereral sproutings of weeds have been destroyed by cultivation, but in districts where the summer months are very dry the seed must be sown sufficiently early to permit good growth on the part of the young plant, that it may withstand the drought of later on.

\section{AFTER-TREATMENT.}

The first two seasons are critical ones in the life of the plant. 'The field must be mown as often as the (rop reaches a height of $S$ or 10 inches, and blooms must not be allowed to appear. Cutting liceps wceds in check, aids root-lerelopment, and encourages growth. When growtl comes to a standstill, or when plants turu sellow, the mower is needed. The cutter-bar should be kept 5 inches away from the ground during the first year, and the clippings, unless exceedingly heary, must be left to serve as a luulch. Do not mow too late, that the (rop may enter upon the winter with a growth of several inclies for its protection. A rery heary growth left at this time, however, is undesirable.

If a nurse crop is present, no attention is necessary curing its growing period, but as harvest approaches the grain must not be allowed to smother the young alfalfa-plants ly lodging. Cut the grain at least 5 inches from the ground, and remove the shocks as quickly as possible, in no case allowing them to stand on the same spot for more than two days at one time.

When the second vear arrives, mow early to keep down the weeds. If a good stand is obtained this season, hereafter the plant usually does well.

\section{YIELD.}

The yield that may reasonally be expected from alfalfa will depend upon the locality, the 'season, and the rariety used. Sixteen tous of green folder per acre, or 4 tons of hay, should, at least, be secured when the field is well established. The average obtalned for eight years at the Oregon Agricultural Station has been: Of green fodlder, 26.3 tons per acre; or of hay, 6.2 tons.

\section{FERTILIZING REQUIREMENTS.}

Professor J. H. Grisdale, of Ottawa, says: "Just as when sown to clovers and other legumes, loth the physical condition and the arerage plant-food content of a soll are improred and increased rather than injured or depleted by being under alfalfa for a time. Certain amounts of the chief elements of plant-food are, however, removed by each erop, and the application of farmyard manure in the fall, at the rate of, say, 10 tons per acre, every four sears, will prove profitable. If it is desired to supplement an insuficient supply of larnyard manure, the following dressing of commercial fertilizer per acre will most likely be found raluable: $30 \mathrm{ll}$. nitrate of soda, $300 \mathrm{lb}$. kone-meal, and $\leqslant 0 \mathrm{lb}$. muriate of potash. Experiments at Guelph show good results from the tise of superphosphate and Thomas phosphate."

\section{VALUE OF THE SOIL.}

Alfalfa-growing is often recommended for the purpose of improving the soil. Good condition and fertility of soll are certainly necessary to start the crop, but. once started, it is of great ralue in this comnection. Arallable plant-food is adder to the soil by the bacteria, and by the long roots that bring up, from great depths, material which is left in the uppermost layers.

The pliysical improvement in a soil that has grom alfalfa for some time is also very marked. Complared with the ordinary grass and elover sods, that of alfalfa is the most diflicult to plongl, but the inverted sod is far more mollow and frialie than are those of the others. The sod of red clover ploughs easily, and the soll is foumc in good condition. The same may be sald of Mammoth clover. Alsike clover-sou plongls more easily, and benefits the soil rather more than these, while timothy-sod is relatively troublesome to break up, and results in very little improrement in the mechanical condltion below. 


\section{FEEDING VALUE.}

The feeding value of alfalfa not only as hay, but for soiling and pasturing purposes, entitles it to rauk exceedingly higl. Inder joloper condition it also yields a good quality of silage.

Dry Matter and 1)igestible Nutrients in 100 Li.

\begin{tabular}{l|c|c|c|c|c}
\hline \hline & $\begin{array}{c}\text { Dry } \\
\text { Matter. }\end{array}$ & Irotein. & $\begin{array}{c}\text { Carlohy. } \\
\text { drates. }\end{array}$ & $\begin{array}{c}\text { Matty } \\
\text { Matters. }\end{array}$ & $\begin{array}{c}\text { Nutritive } \\
\text { Iratio. }\end{array}$ \\
\hline Green folder .... & 28.2 & 3.9 & 12.7 & 0.5 & $1: 3.5$ \\
Hay ........... & 91.6 & 11.0 & 39.6 & 1.2 & $1: 3.5$ \\
\hline
\end{tabular}

It is as a solling crop for dairy cattle that alfalfa is particularly valuale. It makes a good spring growth and is reakly to cut hefole wost green feeds. It may be cut for this purpose hefore blossoms applear, and will allinit of cuttlug two or more times during the season, depending on the locality. No solling crop apmoaches it in value as a food for milk-production.

As a soiling crop for swine, it may be expected to redice the cost of producing pork 40 per cent. in comparison with swine fed on grain alone. When used for this, it should be cut even earlier than when for feeling to cows. It is also well suited, in this form, for horses aud sheep.

All classes of live-stock thrive upon alfalfa pasture, but before the thiril season it is not advisable to allow animals upon it to any extent, and close cropping at any time is dangerous to the catch. The trampling of stock also harlens the soll, and eventually kills the crowns. Cattle and sleep sometines bloat if allowed to eat alfalfa when wet with rain or dew.

Mixed with corn or red clover, alfalfa appears to give better losults in the silo than when alone, though by itself it has, in some lands, mate good ensilage. Professor Henry states, with regarl to clovers in general: "It would appear that the best quality of silage is secured by cutting at the usua? time for luamaling, and allowing the plants to lose a part of their moisture by wilting before they are placed in the silo."

\section{HAY.}

Alfalfa hay well male has no egual as a dry feed for live-stock, but it demands, in the making, more cale and skill than does any othel kink.

As the plants blossom, their stems lecome wooly and, if far advanced in the flowering stage, lose their leaves easily, modnciug indigestible and fuferior hay. They should, therefore, be cut when blossoms commence to alpenr. If the field is uniform, the proper stage may be sald to be reached wen alont one-tenth of the plants are in bloom.

In the curing and honsing. the crop should be handled as little as possllue, to avoid the loss of leaves, which are by fau the most valuable part. If exposed to rain during curing, alfalfa lay loses probably lalf its value. When the crop is well wilted after cutting, rake into windrows, and finish the curng process in the windrow and in the cocks juto which it should soon he put. A (ap) for corering the cocks during the curing will le found of service.

The following is taken from Bulletin No. 313 of the Genera Agrienltural stutlou, N.Y., on "Inoculation and Jime as Factors in growing .lfalfa," unel muy he of intelest :-

\section{"SUMMARY.}

“1. The results from more than 100 co-operatlve experimbents in growing alfalfa indicate that where neither llme not inoculation is apllied, the clance of a successul crop is not more than 20 per cent., or one chance in five. 
" 2 . Where lime is added to the land at the rate of $1,500 \mathrm{lb}$ per acre, the chance of success is raised to 40 per cent., or two out of five.

" 3 . Where inoculation soil is applied alone, at the rate of 200 to $300 \mathrm{lb}$. per acre, the chance of success is raised to about 60 per cent., or three chances out of fire.

" 4 . Where both lime and inoculation are applied as above indicated, the chance of a successful crop is raised to about four out of five.

" 5 . Each farmer intending to try the growing of alfalfa should at first restrict his seeding, and so arrange a small acreage as to determine what line of treatment is required by his fields." 


\section{BULLETINS ISSUED BY THE DEPARTMENT OF AGRICULTURE.}

No. 7.-Flax.

8.-Feeding Farm Animals.

, 20.-Varieties of Fruit IRecommended. (Revised.)

, 25.-Orchard Cleansing.

"28. - Production of Liggs.

"29.-Poultry Industry on the Pracific Coast.

"30.-Gulde to Bee-keeping in British Columbia.

,. 32.-Control of Bovine Tuberenlosis ln British Columbia.

, 33.-Fruit-growing Possibilities, Skeena River and I'orcher Island I)istricts.

, 34.-Fruit-trees and Black-spot Canker.

", 35. -The Place and I'vrpose of Family Life.

" 36. - The Preparation of Food.

" 37. - The Preservation of Food.

" 38. - The Construction of silos.

" 39.-Natural and Artificial Inenbation and Brooding.

" 40.-Alfalfa.

" 41.-Labour-saving Devices in Household.

Applications for bulletins published by the Department of Agriculture should be addressed to the Secretary, Department of Agriculture, Victoria, B.C.

VICTORIA, B.C. :

Printed by Wilian H. Culdin, Printer to the King's Most Excellent Mijests.

1014. 



\section{UNIVERSITY OF CALIFORNIA LIBRARY}

RETURN TO the circulation desk of any University of California Library

or to the

NORTHERN REGIONAL LIBRARY FACILITY

Bldg. 400, Richmond Field Station

University of California

Richmond, CA 94804-4698

ALL BOOKS MAY BE RECALLED AFTER 7 DAYS

- 2-month loans may be renewed by calling (510) 642-6753

- 1-year loans may be recharged by bringing books to NRLF

- Renewals and recharges may be made 4 days prior to due date.

DUE AS STAMPED BELOW

\section{MAR 271999}




\section{$\bar{N} \times 5947 ?$}

$$
\begin{aligned}
& 5141 \\
& A 4 \\
& n o .32-40
\end{aligned}
$$

THE UNIVERSITY OF CALIFORNIA LIBRARY 
